\title{
EVALUARE EPIDEMIOLOGICĂ ŞI PSIHO-SOCIALĂ A COPILULUI OBEZ - STUDIU PROSPECTIV
}

\author{
Oana Elena Iaru ${ }^{1}$, Raluca Maria Vlad ${ }^{1,2}$, Marina Popov ${ }^{1}$, Roxana Andrei ${ }^{1}$, \\ Irina Dijmărescu ${ }^{1}$, Daniela Păcurar ${ }^{1,2}$, Dumitru Orăşeanu ${ }^{1,2}$ \\ ${ }^{1}$ Clinica Pediatrie, Spitalul Clinic de Urgență pentru Copii ,, Grigore Alexandrescu“, \\ Bucureşti \\ ${ }^{2}$ Universitatea de Medicină şi Farmacie ,, Carol Davila “, Bucureşti
}

\begin{abstract}
REZUMAT
Obiectiv. Studiul de față şi-a propus evaluarea unor parametri epidemiologici şi psiho-sociali într-un eşantion de copii supraponderali şi obezi spitalizați pentru diverse patologii. Durata studiului a fost de 12 luni. Material şi metodă. S-a efectuat un studiu prospectiv, fiind incluşi 78 de copii (6-18 ani) supraponderali (IMC peste percentila 85) şi obezi (IMC peste percentila 95). Criteriul de excludere din studiu a constat în prezența unei patologii corelate cu obezitatea secundară. S-a aplicat un chestionar complex care a cuprins factorii de risc familiali şi personali, evaluarea psihologică şi evaluarea calității vieții conform chestionarului PedsQL. Pentru fiecare pacient s-a efectuat evaluare clinică, a parametrilor de laborator şi imagistică (ecografie abdominală). Rezultate. Dintre copiii incluşi în studiu, 55 au un părinte supraponderal şi 15 au ambii părinți cu exces ponderal. Ancheta alimentară a dezvăluit greşeli alimentare în rândul a 65 de pacienți (83,3\%). Timpul mediu zilnic alocat televizorului şi calculatorului este crescut (5,7 ore/zi) comparativ cu timpul alocat activității fizice acasă şi la şcoală $(0,57$ ore/zi).

Concluzii. Obezitatea a fost asociată cu riscul familial, erori în programul şi conținutul alimentației, timpul scăzut alocat activității fizice şi timpul prelungit petrecut în fața calculatorului sau televizorului. Aceste repere trebuie avute în vedere în programele profilactice şi curative ale acestei patologii.
\end{abstract}

Cuvinte cheie: obezitate, populație pediatrică, anchetă alimentară, activitate fizică

\section{INTRODUCERE}

Obezitatea reprezintă o problemă mondială a populației adulte, atât în țările în curs de dezvoltare, cât mai ales în țările dezvoltate. Conform unei statistici a Organizației Mondiale a Sănătății, prevalența obezității aproape s-a dublat în intervalul 19802008 (1), estimându-se că aproximativ 50\% din populația adultă a Europei este supraponderală. Aceste statistici devin cu trecerea timpului din ce în ce mai adaptate şi populației pediatrice: pentru America datele arată că în ultimii 30 de ani prevalența obezității s-a dublat în rândul copiilor, statisticile pentru anul 2012 dezvăluind că mai mult de o treime dintre copii sunt supraponderali/obezi (2); discuţia este valabilă şi pentru Europa, unde unul din 3 copii cu vârsta de 11 ani este supraponderal sau obez (3).
Urbanizarea, dieta nesănătoasă şi sedentarismul reprezintă factori majori ai creşterii obezității infantile, mai ales în țările dezvoltate (4). Factorii predispozanți pentru modul de viaţă ce duce la apariția obezității se regăsesc atât în familie (majoritatea copiilor obezi având în familie rude obeze), cât şi în societate (dezvoltarea rețelelor fast-food, creşterea timpului petrecut în fața calculatorului sau televizorului). Rezultatul este, de cele mai multe ori, un copil cu probleme de sănătate în prezent şi mai ales în viitor, cu o părere proastă despre sine, neintegrat în colectivitate şi care-şi face cu dificultate prieteni.

\section{MATERIAL ŞI METODĂ}

Am efectuat un studiu observațional, prospectiv, în care au fost incluşi copii cu vârste cuprinse între 
6 şi 18 ani, supraponderali (IMC mai mare de percentila 85) şi obezi (IMC mai mare de percentila 95) internați în cadrul Clinicii de Pediatrie a SCUC „Grigore Alexandrescu“ Bucureşti în perioada iulie 2014 - iunie 2015.

Pacienții au fost selectați în urma internării pentru o altă patologie, de cele mai multe ori acută, de obicei fără legătură cu obezitatea; criteriile de selecție au fost reprezentate de parametrii antropometrici (în primul rând IMC mai mare de percentila 85 corespunzătoare sexului şi vârstei).

Fiecărui pacient selectat i s-a aplicat un chestionar de studiu cu întrebări legate de: date paşaportale, antecedente heredo-colaterale (boli cardiace, sindrom metabolic, afectare hepatică, diabet zaharat tip II, obezitate), statusul nutrițional în familie (cu evaluarea mai ales a statusului nutrițional al părinților), ancheta alimentară a familiei şi a pacientului, evaluarea activității fizice depuse acasă şi la şcoală, dar şi a sedentarismului, evaluare psihologică (conflicte în familie, conflicte la şcoală), antecedente personale patologice (afectare respiratorie, migrenă), indici antropometrici, examen fizic, investigații de laborator specifice (funcție renală, hepatică, profil lipidic, proteic şi glicemie), ecografie abdominală (pentru identificarea steatozei hepatice). Pentru fiecare pacient înrolat şi părinții săi s-a efectuat evaluare psihologică pentru aprecierea calității vieții utilizând chestionarele PedsQL (5).

Datele au fost înregistrate şi prelucrate statistic cu Microsoft Excel.

Studiul a fost aprobat de Comisia de Etică a SCUC „Grigore Alexandrescu“, iar pentru fiecare pacient înrolat unul dintre aparținători a semnat un formular de consimțământ informat.

\section{REZULTATE}

Lotul de studiu a cuprins un număr de 78 de pacienți cu vârste între 6 şi 18 ani, dintre care 33 fete şi 45 băieți, cu vârsta medie 138 luni, respectiv 11 ani şi 6 luni. În funcție de indicele de masă corporală, 51 pacienți, respectiv $65,38 \%$, sunt obezi (IMC mai mare de percentila 95 pentru sex şi vârstă) şi 27 pacienți $(34,62 \%)$ sunt supraponderali (IMC între percentilele 85 şi 95 corespunzătoare pentru vârstă şi sex).

O mare parte dintre pacienți prezintă anchetă familială pozitivă pentru exces ponderal (supraponderali/obezi) - 58 copii, respectiv 74,35\% (chestionarul a fost adresat țintit astfel încât să fie selectate doar rudele apropiate, cu care copilul are contact frecvent/îndelungat, membri ai familiei ce ar putea constitui modele de comportament). În ceea ce priveşte prevalența excesului ponderal în rândul părinţilor, rezultatele sunt următoarele: 55 copii au un părinte supraponderal/obez şi 15 dintre aceştia au ambii părinți cu exces ponderal (Fig. 1).

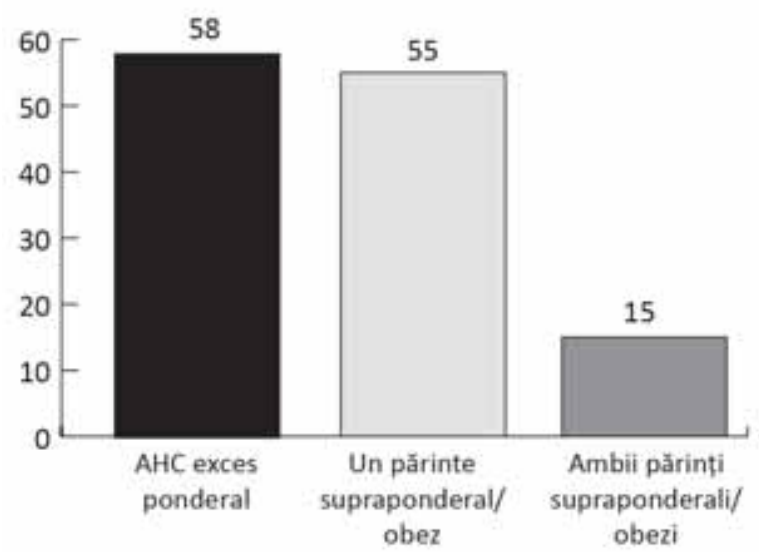

FIGURA 1. Anchetă familială obezitate

Analizând datele cu privire la ancheta alimentară, chestionarul aplicat a arătat erori în alimentație pentru marea majoritate a pacienților (65 dintre cei 78 de pacienți, respectiv $83,3 \%$ ). Erorile la capitolul alimentație apar atât în ceea ce priveşte orarul meselor (mese haotice, program de masă dezorganizat $-42,3 \%$; lipsa uneia din mesele principale, mese la ore nepotrivite $-28,2 \%$, gustări frecvente - 61,5\%), cât mai ales în ceea ce priveşte calitatea lor: carbohidrații în exces (atât sub formă de dulciuri, dar şi în cadrul meselor principale - pâine, paste) fac parte din dieta a 61 de copii din lotul de studiu (respectiv 78,2\%), iar prăjelile şi lipidele saturate excesive se regăsesc în dieta zilnică a 32 copii, respectiv $41 \%$. Băuturile carbogazoase sunt consumate zilnic de 43 copii $(55,1 \%)$. În ceea ce priveşte alimentaţia de tip fast-food, majoritatea copiilor o primesc ocazional, dar 29 dintre ei (respectiv $37,1 \%$ ) consumă fast-food în mod regulat (cel puțin o dată pe săptămână) - date reprezentate în Fig. 2.

Un alt capitol din analiza modului de viață caracteristic pacienților supraponderali/obezi este reprezentat de sedentarism, respectiv timpul petrecut în fața televizorului, calculatorului şi altor deviceuri (tabletă, smart phone) plus cantitatea de timp dedicată jocurilor pe calculator. Timpul mediu alocat calculatorului, respectiv jocurilor pe calculator, este 3,2 ore/zi, respectiv 22,4 ore/ săptămână (Fig. 4 şi Fig. 5), iar timpul mediu petrecut în fața televizorului este 2,5 ore/zi, respectiv 17,5 ore/săptămână (Fig. 3).

În contrast cu activităţile sedentare, activitatea fizică nu ocupă o parte importantă a programului 


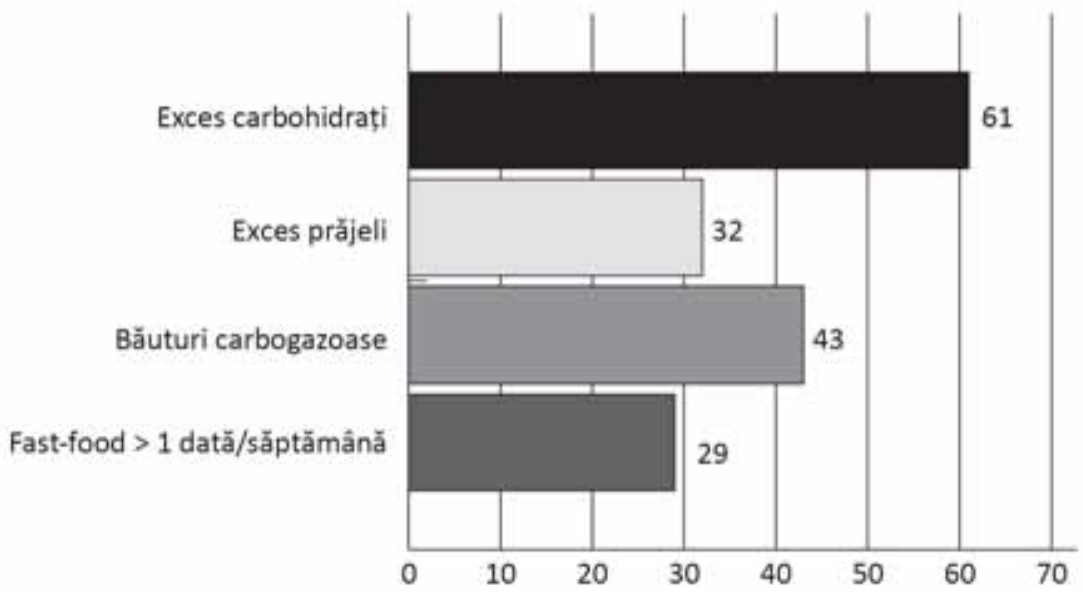

FIGURA 2. Anchetă alimentară

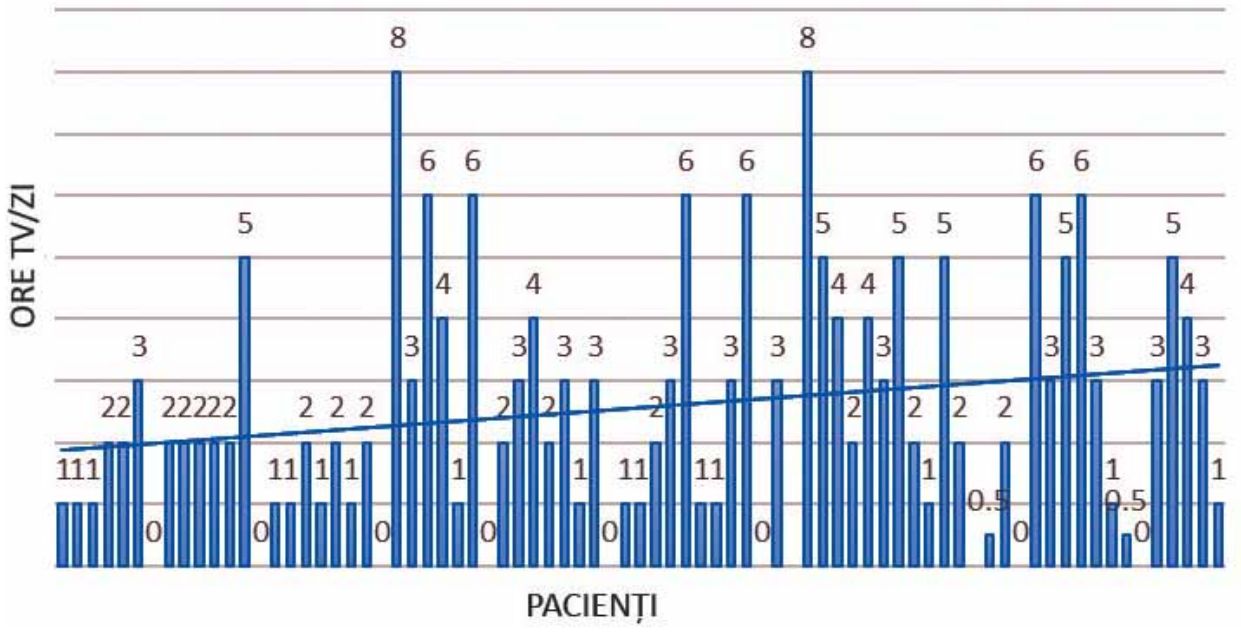

FIGURA 3. Timp petrecut în fața televizorului (medie 2,5 ore/zi)

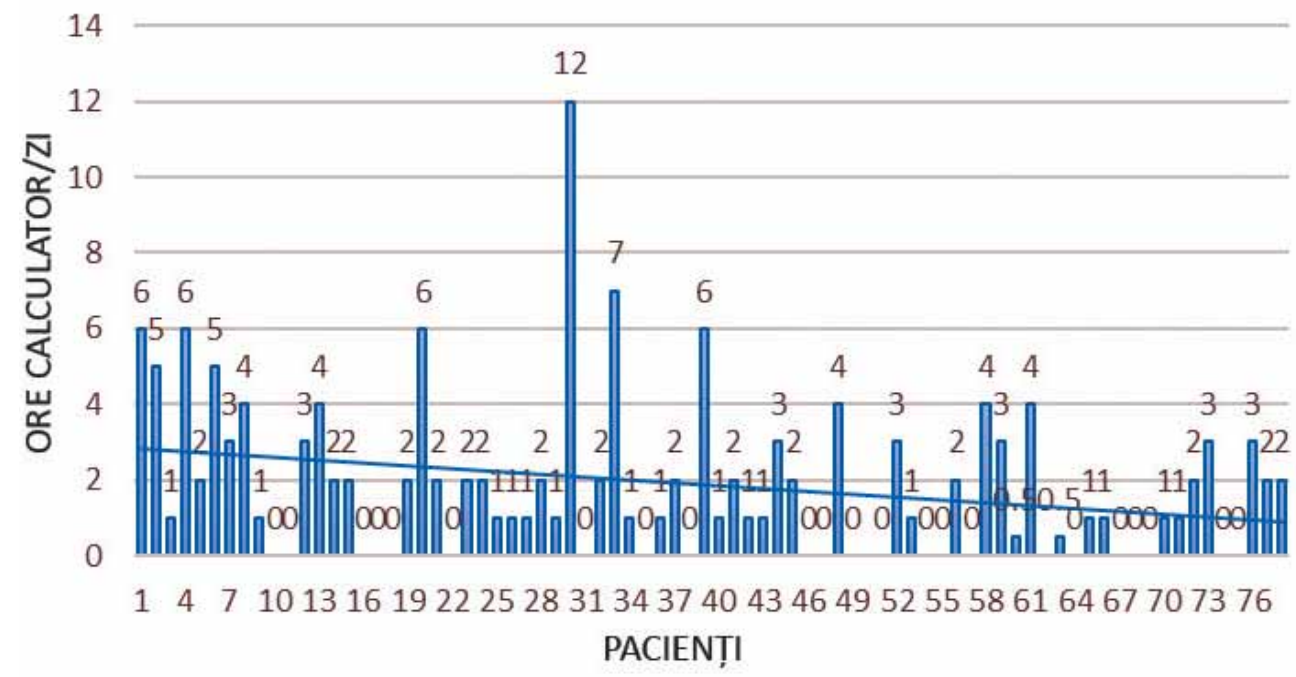

FIGURA 4. Timp petrecut în fața calculatorului (medie 1,8 ore/zi)

zilnic/săptămânal al copiilor. Doar 42 copii practică o formă de activitate fizică zilnic (fie că este vorba de sport într-un cadru organizat sau doar recreațional sau chiar numai de joacă ce implică mişcare). Numărul mediu de ore de sport pe săptămână practicat de copiii incluşi în studiu este 2,9 (respectiv 0,4 


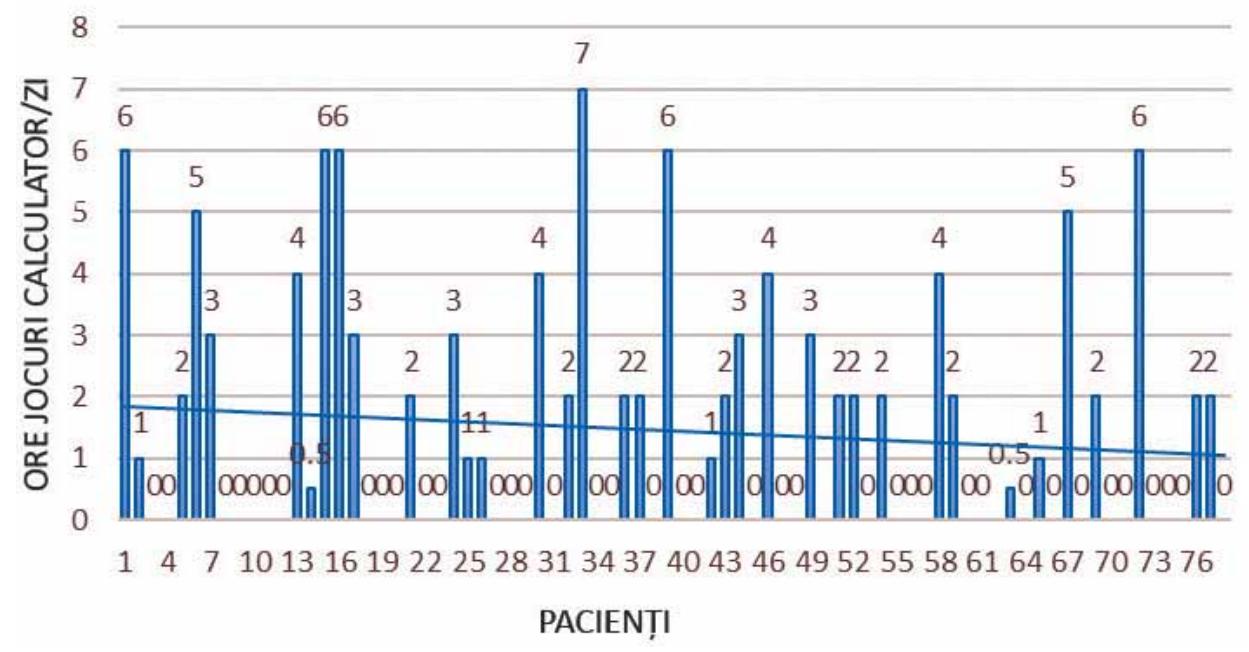

FIGURA 5. Timp petrecut cu jocurile pe calculator (medie 1,4 ore/zi)

ore/zi); la acestea se adaugă orele de educație fizică din programul şcolar, respectiv 1,2 ore/săptămână. De menționat că $23(29,4 \%)$ dintre pacienții incluşi în studiu nu practică educația fizică la şcoală.

Deşi familia nu sesizează de cele mai multe ori relații conflictuale sau probleme de adaptare, prin aplicarea chestionarului de studiu reiese că 30 pacienți $(38,46 \%)$ au relații conflictuale cu unul sau mai mulți dintre membrii apropiați ai familiei (părinţi, fraţi). În ceea ce priveşte relaţiile cu copiii de vârsta lor şi colegii de şcoală, 9 copii (respectiv $11,5 \%$ ) au declarat că nu reuşesc să-şi facă prieteni, iar 13 (respectiv 16,6\%) se simt marginalizați la şcoală.

\section{DISCUȚII}

Obezitatea, problemă de sănătate publică relativ recentă a societății româneşti, îşi face din ce în ce mai mult simțită prezența în rândul populației pediatrice (conform unei anchete realizate în 2014 în cadrul European Childhood Obesity Surveillance Initiative - COSI, un sfert dintre copiii români de 8 ani sunt supraponderali sau obezi) (6). Deşi nu există încă date naționale pentru toate grupele de vârstă, prevalența acestei patologii asociate în rândul copiilor internaţi de obicei pentru alte afecțiuni este în creştere.

Obezitatea în familie, în rândul rudelor apropiate ce pot constitui modele comportamentale pentru copii, dar mai ales în rândul părinților, are un rol important în etiologia obezității copilului. Conform literaturii de specialitate, un copil cu un părinte obez are $50 \%$ şanse de a deveni obez, iar dacă ambii părinţi sunt obezi şansele cresc la $80 \%$ (4). Un alt studiu (7) arată că obezitatea parentală creşte cu mai mult de jumătate riscul ca un copil să devină obez.
În studiul de față, 55 copii (respectiv 70,5\%) au un părinte $\mathrm{cu}$ exces ponderal şi 15 dintre aceştia (respectiv 19,23\%) au ambii părinți supraponderali.

Obezitatea reprezintă dezechilibrul dintre cantitatea de calorii câştigată comparativ cu cantitatea de calorii cheltuită (8). Cantitatea de calorii nefolositoare (,empty calories“) care va participa ulterior la formarea kilogramelor în plus reprezintă aproximativ $40 \%$ din dieta copiilor cu vârste cuprinse între 2-18 ani. Sursele acestor calorii sunt reprezentate de: băuturi carbogazoase, deserturi/gustări, pizza, lapte integral (9). În populația studiată, 61 copii $(78,2 \%)$ consumă carbohidrați în exces, iar 32 copii $(41 \%)$ au cantități crescute de grăsimi saturate în alimentația zilnică. În ceea ce priveşte băuturile carbogazoase, acestea fac parte din programul alimentar zilnic pentru 43 copii (55\%).

Consumul alimentației tip fast-food cel puțin o dată pe săptămână este asociat cu risc crescut de obezitate (10). În lotul de studiu, 29 copii $(37,1 \%)$ consumă fast-food săptămânal.

Într-o evaluare pe o populație americană de adolescenți pentru anul 2013, doar 29\% dintre participanți practicaseră activitate fizică de orice fel cel puțin 60 de minute pe zi, 7 zile consecutiv anterior realizării studiului (recomandările Organizației Mondiale a Sănătății privind activitatea fizică la copii şi adolescenți sunt următoarele: 60 minute activitate fizică moderată zilnic) $(11,12)$. În ceea ce priveşte populația analizată în studiul nostru, activitatea fizică zilnică medie se reduce la 0,4 ore/zi. De menționat că doar 42 copii au în programul zilnic o formă de activitate fizică.

$\mathrm{Cu}$ privire la sedentarism şi timpul petrecut în fața televizorului şi calculatorului, un studiu făcut în 2011 pe o populaţie americană de 12.650 copii de grădiniță arată că petrecerea a mai mult de o oră 
în fața televizorului sau calculatorului zilnic conduce la un risc de câştigare a unui exces ponderal crescut cu 52\%; tot din acest studiu reiese că timpul mediu zilnic petrecut de copii în fața televizorului/ calculatorului este de 3,3 ore (13). În populația românească studiată timpul mediu zilnic acordat televizorului este de 2,5 ore, iar cel alocat calculatorului este de 3,2 ore - semnificativ mai mare comparativ cu timpul acordat activității fizice.

\section{CONCLUZII}

În populația pediatrică studiată obezitatea este asociată cu istoric familial al acestei patologii, mai ales în rândul părinților. Ancheta alimentară a evidențiat erori dietetice la majoritatea pacienților, atât în ceea ce priveşte orarul meselor şi cantitatea alimentelor, cât mai ales în privința principiilor alimentare predominante în alimentaţie. Consumul alimentaţiei tip fast-food reprezintă o obişnuinţă pentru majoritatea participanţilor la studiu, o treime dintre aceştia consumând astfel de produse mai mult de o dată pe săptămână. Timpul mediu alocat activității fizice este foarte scăzut, doar 53\% dintre copiii înrolați în studiu practicând o formă de activitate fizică zilnic. În contrast cu timpul dedicat activității fizice, timpul petrecut în fața calculatorului/televizorului este mai degrabă crescut. 